\title{
Investigating the Plant Species and Rainfall Factors on Stormwater Retention Performance of Extensive Green Roofs in Malaysia
}

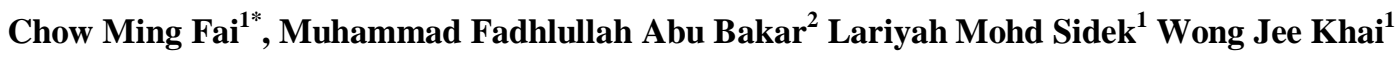 \\ ${ }^{1}$ Sustainable Technology \& Environment Group, Institute of Energy Infrastructures, Universiti Tenaga Nasional, 43000 Kajang, Selan- \\ gor, Malaysia. \\ ${ }^{2}$ Department of Civil Engineering, College of Engineering, Universiti Tenaga Nasional, 43000 Kajang, \\ Selangor, Malaysia. \\ * Corresponding author's e-mail: mingfaichow12345@gmail.com
}

\begin{abstract}
Information on the influences of native plant species and rainfall characteristics on the stormwater retention performance of extensive green roofs in Malaysia is still scarce. More local data is still required because rainfall and runoff generation processes in tropical environment are very different from the temperate regions. This study is aimed to investigate the stormwater retention performance of native plant species in extensive green roofs with respect to different rainfall characteristics in Malaysia. Two test beds consist of pro-mixing potting soil were vegetated each with different native plant species (Axonopus Compressus (cow grass), Portulaca Grandiflora (sedum) and one test bed with no vegetation (bare ground) was prepared as a control. A total of 22 significant storm events were collected over a 3-month period from March 2016 to May 2016. The rainfall depths for monitored storm events were ranged from $4.5 \mathrm{~mm}$ to $63.2 \mathrm{~mm}$ and rainfall intensities ranged from $0.5 \mathrm{~mm} / \mathrm{hr}$ to $58.5 \mathrm{~mm} / \mathrm{hr}$. The results showed that sedum exhibited higher mean runoff retention percentage than grass which is $75.8 \%$ and $70.9 \%$, respectively. Bare soil was the least effective for reducing water runoff with retention percentage of $62.6 \%$. Overall, sedum and grass species provided $90.6 \%$ and $88.2 \%$ of cumulative rainfall retention in this study. The rainfall depth and intensity are correlated negatively with stormwater retention performance of green roofs. Meanwhile, longer dry weather period are likely to increase the water retention capacity of green roof.
\end{abstract}

Keywords: Green roof, native plant species, rainfall characteristic, stormwater management, tropical environment

\section{Introduction}

Malaysia is moving towards becoming a high income and developed country by the year 2020. Thus, the tier of urban growth is increasing rapidly in the recent years and this growth is expected to reach $85 \%$ by the year of 2030 [1]. Development entities such as road, walkway and building have replaced the forests, wetland, and grassland that subsequently cause the increasing of storm water runoff volume, the decreasing of evapotranspiration, river erosion, diminishing of ground water recharge, as well as enhancing stream channel $[2,3,4,5,6]$. As the developments are progressing, greater challenges are imposed on managing and reducing the stormwater runoff in urban areas. Rooftop and transport systems commonly account for $80 \%$ of all the impervious surfaces in the urban area [7]. Rooftop runoff poses a greater threat to water quantity in urban catchment than rural catchment as the runoff can enter the receiving water bodies more rapidly due to the greater connectivity of roofs to drainages. Green roof have been implemented widely in developed temperate countries like USA, Canada and European countries. However, only limited studies were carried out in Malaysia, despite the fact that, Malaysia has great potential in the developments of green roof. There is significant outcome in learning from findings and guidelines that have been developed in other countries. However, climatic variations between the temperate and tropical regions hinder the direct transferal of roof designs, substrate specifications, and plant species. In fact, the tropical climate in Malaysia is characterized by warm weather in the morning and afternoon, followed by high intense and short duration thunder storm in the evening. The monsoon seasons during March-May and October-December also bring large amount of rainfall to Malaysia. Dry season especially during February has caused prolonged drought period in many urban cities in Malaysia. This climate condition is totally different from the other region such as America, Canada or Europe, particularly on rainfall distribution all over the year.

In view of a better implementation of green roofs in Malaysia, there seems to be a great need to find out the best plant species that is acceptable for green roofs in the tropical climate region. Presently, selection of plant species is normally considered only single species for each green roof and chosen solely based on their capability to tolerate with shallow substrates and drought conditions. It is found that most of the suitable green roof plant species are sempervivums, exotic sedums and other species that have been confirmed to be able to sustain the harsh environments on rooftop $[8,9,10,11,12,13]$. Unfortunately, selection of these plant species can only develop green roofs with minimal ability for nutrient cycling function, wildlife use, and other ecological purposes [14]. 
It is suggested by recent research that native plant species selection could contribute to the improvement of green roof aesthetic potential as well as ecological function.

The tropical climate in Malaysia offers a unique situation for green roofs because of higher rainfall intensity, higher temperatures and higher potential evaporation rates. The acceptant of green roofs is rely extremely on local weather conditions, and expecting green roof achievement by relying on experiences from temperate climate countries only without local evaluation is problematic $[15,16]$. Therefore, local green roof studies must be carried out in order to assess the suitable native plant species for stormwater mitigation potential of a particular region. The benefits of choosing native plants in green roof systems are including better adapted to local condition, require less watering and low maintenance, increase biodiversity as well as more aesthetically pleasing than non-native plant. Even though these advantages have been found in other temperate countries, the number of research related to stormwater retention performance with respect to native plants in green roof systems is still lacking in Malaysia Therefore, this study is carried out to determine the effects of native plant species and rainfall characteristics on stormwater retention performance of extensive green roofs.

\section{Experimental Green Roof Design and Set Up}

This experiment was conducted at the rooftop level of College of Engineering building in Universiti Tenaga Nasional (UNITEN). A total of three green roof test beds were set up in this study. The dimension of each green roof test bed is $1.0 \mathrm{~m}$ length $\mathrm{x} 0.5 \mathrm{~m}$ width $\times 0.2 \mathrm{~m}$ height, and installed at a height of $1 \mathrm{~m}$ above the roof top level with a slope of $1.5 \%$. Each green roof test bed was placed at a custom made raised steel structure that equipped with a drainage pipe and runoff harvesting tank. Fig. 1 shows the experimental green roof test beds that established in this study. The typical potting soil was chosen in this study for investigating its stormwater retention performance and influences on the soil moisture content behaviour in extensive green roofs. The choice of this substrate type was based on its availability and popularity as common horticultural substrate used by the local landscaping industry. The use of locally available substrates is important for the growth of selected native plant species in green roofs. The substrate layer was fixed as $130 \mathrm{~mm}$ depth and placed on top of the filter fabric and drainage layers (Fig. 1). The green roof test bed was planted with each native plant species which is Axonopus compressus (grass) and Portulaca Grandiflora (sedum) as shown in Fig. 2. All surface areas inside the green roof test bed were ensured that $100 \%$ covered by the respective plant. Weeds or unnecessary plants found in the green roof test bed were removed every week manually throughout the monitoring period, in order to maintain the species composition and consistency of results. As a control, bare potting soil with no vegetation was also prepared in this study.

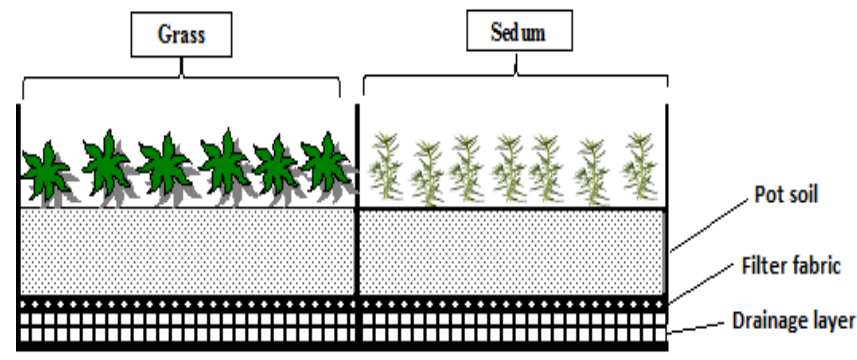

Fig. 1. Experimental green roof test beds that established in this study

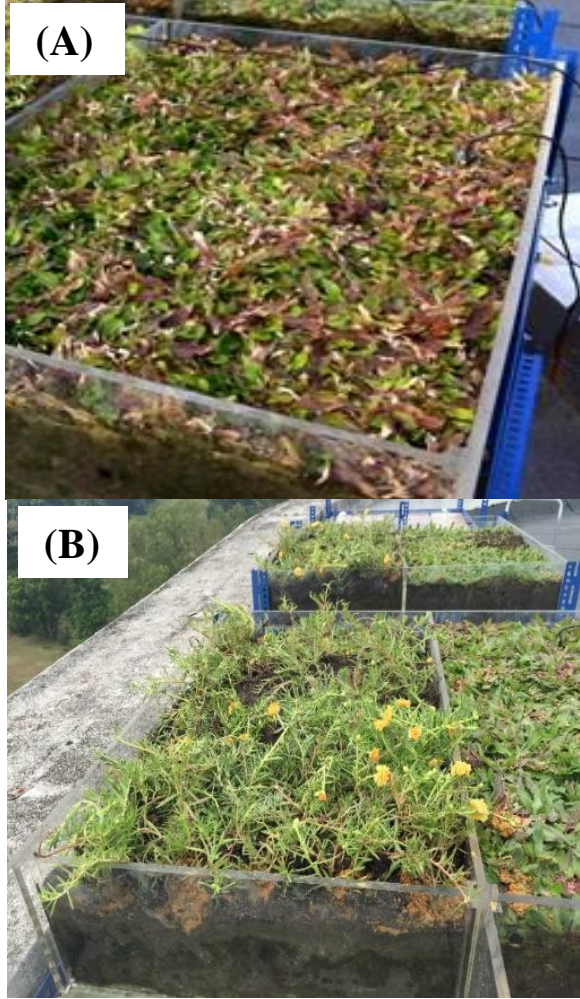

Fig. 2. Axonopus compressus (A) and Portulaca Grandiflora (B) that planted in the green roof test beds

\section{Data Collection and Analysis}

A Watchdog tipping bucket rain gauge with $0.2 \mathrm{~mm}$ resolution was installed at the rooftop level to measure the rainfall depth at 1 minute interval. The rainfall data during the monitoring period was analysed in terms of total depth, total duration, mean intensity, maximum rainfall intensity and antecedent dry days (ADD). The storm events were further categorized according to its return period and size. The individual event was defined as being separated by continuous dry periods of at least 6 hours. This definition was selected in accordance with Rowe et al. [17] and Getter et al.[18]. The stormwater runoff that discharged from drainage layer within the green roof test beds was drained out by using a PVC pipe. A runoff harvesting tank was placed under the green roof test beds and connected to the PVC pipe in order to collect the runoff from green roofs. The water volume in the runoff harvesting tank was measured immediately after the storm event finished. The stormwater retention percentage of green roof is generally calculated by dividing the difference between rainfall and runoff depths with the total rainfall depth as shown in Equation 1. The average retention percentage, AR (\%) is calculated by averaging the retention percentage of individual rainfall events while total retention percentage, TR $(\%)$ is calculated by dividing the cumulative green roof runoff with cumulative rainfall depth over the study period. The formulas for $\mathrm{AR}$ and $\mathrm{TR}$ are presented in Equations 2 and 3, respectively.

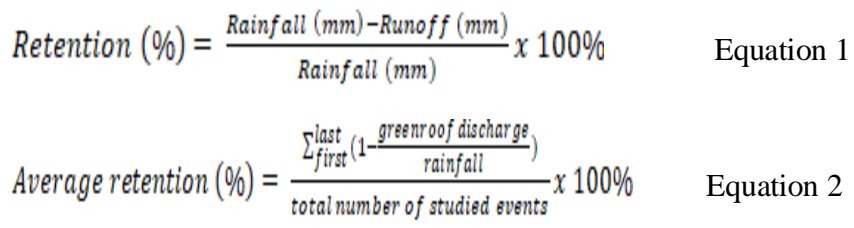

Total retention $(\%)=\frac{\sum \text { green roof discharge }}{\sum \text { rainfall }} \times 100 \% \quad$ Equation 3 


\section{Results and Discussion}

A total of 22 significant storm events were collected over a 3month period from March 2016 to May 2016. The rainfall depths for monitored storm events were ranged from $4.5 \mathrm{~mm}$ to $63.2 \mathrm{~mm}$ and rainfall intensities ranged from $0.5 \mathrm{~mm} / \mathrm{hr}$ to $58.5 \mathrm{~mm} / \mathrm{hr}$. The rainfall characteristics for all monitored storm events are presented in Tab. 1. The stormwater retention performance of each green roof test bed is assessed in detail in terms of average retention (AR) and total retention (TR) percentages, by using event-based and cumulative assessment approaches, respectively. The differences in retention performance between rainfall types and green roof configurations are also studied in depth. The stormwater retention percentage is calculated for every storm event monitored in each green roof configuration and the results are summarized in Tab. 1. The boxplots of stormwater retention percentages for every green roof configuration are shown in Fig. 3. Great variations of stormwater retention percentages are observed for all test beds in this study. Interestingly, both green roof test beds show higher median values of stormwater retention percentages compared to bare soil test bed.

Tab. 1. Stormwater retention performances of different plant species in extensive green roof

\begin{tabular}{|c|c|c|c|c|c|c|c|}
\hline \multirow{3}{*}{ No } & \multirow{3}{*}{ Date } & \multirow{2}{*}{\multicolumn{3}{|c|}{$\begin{array}{c}\begin{array}{c}\text { Retention percentage } \\
(\%)\end{array} \\
\text { Test bed } \\
\end{array}$}} & \multicolumn{3}{|c|}{ Rainfall characteristic } \\
\hline & & & & & \multirow{2}{*}{$\begin{array}{c}\text { Dept } \\
\text { h } \\
(\mathbf{m m})\end{array}$} & \multirow{2}{*}{$\begin{array}{c}\text { Intensi- } \\
\text { ty } \\
(\mathbf{m m} / \mathbf{h r} \\
)\end{array}$} & \multirow{2}{*}{$\begin{array}{c}\text { Dry } \\
\text { day } \\
\text { (day }\end{array}$} \\
\hline & & Grass & $\begin{array}{c}\text { Se- } \\
\text { dum }\end{array}$ & $\begin{array}{c}\text { Bare } \\
\text { soil }\end{array}$ & & & \\
\hline 1 & 05-Mar & 80.38 & 83.87 & 72.58 & 9.3 & 0.5 & 14 \\
\hline 2 & 10-Mar & 80.69 & 84.65 & 69.31 & 10.1 & 1.5 & 5 \\
\hline 3 & 15-Mar & $\begin{array}{r}100.0 \\
0 \\
\end{array}$ & 100.00 & 57.45 & 4.5 & 1.0 & 5 \\
\hline 4 & 16-Mar & $\begin{array}{r}100.0 \\
0\end{array}$ & 100.00 & 59.43 & 5.3 & 1.0 & 1 \\
\hline 5 & 20-Mar & 80.36 & 84.18 & 69.90 & 9.3 & 1.5 & 4 \\
\hline 6 & 25-Mar & $\begin{array}{r}100.0 \\
0 \\
\end{array}$ & 100.00 & 85.32 & 18.7 & 1.0 & 5 \\
\hline 7 & 04-Apr & 66.01 & 75.50 & 55.53 & 30.1 & 58.5 & 10 \\
\hline 8 & 05-Apr & 51.32 & 66.65 & 50.94 & 39.6 & 19.8 & 1 \\
\hline 9 & 24-Apr & 57.64 & 68.66 & 51.11 & 40.6 & 20.3 & 19 \\
\hline 10 & 29-Apr & 64.56 & 65.78 & 62.38 & 10.1 & 4.9 & 5 \\
\hline 11 & 30-Apr & 68.69 & 75.46 & 55.16 & 21.6 & 14.4 & 1 \\
\hline 12 & $\begin{array}{l}02- \\
\text { May }\end{array}$ & 59.39 & 71.04 & 54.88 & 59.0 & 39.3 & 2 \\
\hline 13 & $\begin{array}{l}\text { 04- } \\
\text { May }\end{array}$ & 61.67 & 68.61 & 54.74 & 22.5 & 15.0 & 2 \\
\hline 14 & $\begin{array}{c}05- \\
\text { May }\end{array}$ & 68.72 & 71.00 & 66.44 & 21.1 & 16.1 & 1 \\
\hline 15 & $\begin{array}{l}\text { 06- } \\
\text { May }\end{array}$ & 72.12 & 66.78 & 63.47 & 29.2 & 16.1 & 1 \\
\hline 16 & $\begin{array}{c}07- \\
\text { May }\end{array}$ & 67.15 & 78.12 & 62.89 & 63.2 & 31.1 & 1 \\
\hline 17 & $\begin{array}{c}08- \\
\text { May }\end{array}$ & 69.43 & 74.19 & 65.08 & 24.3 & 24.3 & 1 \\
\hline 18 & $\begin{array}{c}11- \\
\text { May }\end{array}$ & 69.96 & 75.64 & 65.90 & 59.7 & 26.5 & 3 \\
\hline 19 & $\begin{array}{l}14- \\
\text { May }\end{array}$ & 70.47 & 61.01 & 55.05 & 18.7 & 12.5 & 3 \\
\hline 20 & $\begin{array}{c}15- \\
\text { May }\end{array}$ & 60.79 & 72.98 & 60.62 & 44.1 & 22.7 & 1 \\
\hline 21 & $\begin{array}{l}21- \\
\text { May }\end{array}$ & 54.93 & 61.09 & 72.54 & 13.8 & 6.9 & 6 \\
\hline 22 & $\begin{array}{l}24- \\
\text { May }\end{array}$ & 56.94 & 63.73 & 69.51 & 17.1 & 11.4 & 3 \\
\hline & Mean & 70.9 & 75.8 & 62.6 & & & \\
\hline
\end{tabular}

The monoculture of Portulaca Grandiflora (sedum) is more effective in retaining stormwater with averagely retaining $75.8 \%$ of total rainfall volume. In contrast, the green roof test bed planted with Axonopus Compressus (cow grass) is only capable to retain the rainwater volume of $70.9 \%$. Obviously, Portulaca Grandiflora is capable to retain stormwater with averagely $5 \%$ higher than the Axonopus Compressus (cow grass) species. Previous works have also identified sedum species as the most effective plant in extensive green roofs because of their ability for limiting transpiration, storing excess water, drought tolerance and shallow substrate adaptability. Bare soil was the least effective for reducing water runoff with retention percentage of $62.6 \%$. It was proved that vegetation had a great influence on the stormwater retention performance in extensive green roof. Overall, sedum and grass species provided the total retention percentage of $90.6 \%$ and $88.2 \%$, respectively in this study. Bare soil only exhibited the total retention percentage of $85.9 \%$ in retaining the water runoff volume. In overall, green roof planted with Portulaca Grandiflora (sedum) performs better than others in retaining the stormwater runoff volume. These results show that green roof provides the benefit of stormwater runoff volume reduction and is useful for stormwater management in the urban area.

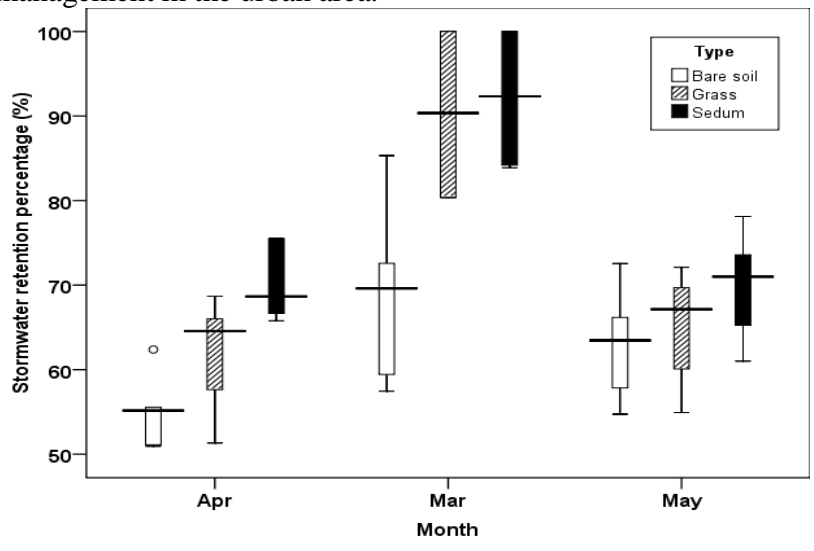

Fig. 3. Boxplots of stormwater retention percentages for different green roof configurations.

\subsection{Effects of Rainfall Characteristics on Stormwater Retention Performance}

The effects of rainfall characteristic on the stormwater retention performance for each green roof test bed have been investigated and the correlation results are presented in Tab. 2. The rainfall depth and intensity both show negative correlations with stormwater retention percentages of green roofs. Meanwhile, bare soil test bed correlated significantly negatively $(r=-0.459)$ with rainfall intensity. These observations explain that the stormwater retention performance of green roofs is decreasing with the occurrence of heavy and intense storm events. Voyde et al. [19] also stated that the retention performance of green roof would be expected to be reduced for larger storm events. Villarreal and Bengtsson [20] reported the same outcome which higher retention rate was observed for lower rainfall intensity in green roofs instead of higher intensity. Getter et al. (2007) [18] also found that the retention values of green roofs were highest for light rain event and lowest for heavy rains. VanWoert et al. [10] stated that an extensive green roof can retain up to $96 \%$ of total light rainfall $(<0.2 \mathrm{~cm}), 83 \%$ of total medium rainfall $(0.2-0.6 \mathrm{~cm})$, and $52 \%$ of total heavy rainfall $(>0.6 \mathrm{~cm})$, respectively. These results have suggested that the rainfall characteristics will affect the rainwater retention rate of green roof, in which higher rainfall magnitude will decrease the stormwater retention performance of extensive green roofs. On the other hand, the dry day period correlated positively with stormwater retention performance of all test beds in this study. The longer dry weather period more likely will cause greater moisture loss from the soil medium and thus increases the water retention capacity of green roof. 
Tab 2. Correlations between stormwater retention percentages and rainfall characteristics

\begin{tabular}{|c|c|c|c|}
\hline \multirow[b]{2}{*}{ Test bed } & \multicolumn{3}{|c|}{ Rainfall characteristic } \\
\hline & Rainfall depth & $\begin{array}{l}\text { Rainfall } \\
\text { Intensity }\end{array}$ & Dry day \\
\hline Axonopus Compressus (cow grass) & -0.361 & -0.324 & 0.054 \\
\hline Portulaca Grandiflora (sedum) & -0.004 & -0.030 & 0.146 \\
\hline Bare pot soil & -0.315 & $-0.459^{*}$ & 0.009 \\
\hline
\end{tabular}

\section{Conclusions}

This study has investigated the stormwater retention performance of different plant and substrate types in extensive green roofs with respect to different rainfall characteristics in Malaysia. The results showed that sedum planted green roof exhibited higher mean runoff retention percentage than that of grass species which recorded $75.8 \%$ and $70.9 \%$, respectively. Bare soil is the least effective test bed for reducing water runoff volume with average retention percentage of $62.6 \%$. Overall, sedum and grass species provide an average of $90.6 \%$ and $88.2 \%$ of total rainfall retention percentages in this study, respectively. The rainfall depth and intensity both show significant negative correlations with stormwater retention performance of green roofs. Meanwhile, the dry day period is correlates positively with the stormwater retention performance of green roofs in this study.

\section{Acknowledgement}

The authors would like to thank Ministry of Higher Education, Malaysia (MOHE) for providing the research grant (Vot no: 20140130FRGS). We would like to acknowledge the BOLD Research Grant provided by Universiti Tenaga Nasional (Project No. $10289176 / \mathrm{B} / 9 / 2017 / 50$ ) and thank the financial supports from Tenaga Nasional Berhad (Project No. U-TG-RD-17-06).

\section{References}

[1] United Nations. 2002. World Urbanization Prospects: The 2001 Revision. United Nations, New York.

[2] Arnold Jr. C. L., \& Gibbons C. J. 1996. Impervious Surface Coverage: The Emergence of a Key Environmental Indicator. Journal of the American Planning Association, 62(2), 243-258.

[3] Stone Jr.B. 2004 Paving over paradise: how land use regulations promote residential imperviousness. Landscape and Urban Planning, 69, 101-113.

[4] Walsh C. J., Fletcher T. D., \& Ladson A. R. 2005. Stream restoration in urban catchments through redesigning stormwater systems Looking to the catchment to save the stream. Journal of the North American Benthological Society, 24, 690-705.

[5] Yusop Z., Chow, M.F. 2008. A review of event mean concentration (EMC) for urban stormwater runoff, Proc. International Conference on Environmental Research and Technology, 1-6.

[6] Kok, K.H.; Mohd, S.L.; Chow, M.F.; Zainal Abidin, M.R.; Basri, H.; Hayder, G. 2016. Evaluation of green roof performances for urban stormwater quantity and quality controls. Int. J. River Basin Manag. 14,1-7.

[7] Slonecker E. T., \& Tilley J. S. 2004. An evaluation of the individual components and accuracies associated with the determination of impervious area. GIScience and Remote Sensing, 41(2), 165-184.

[8] Durham A. K., VanWoert N. D., Rowe D. B., Rugh C. L., \& Ebert D. 2004. Evaluation of Crassulaceae species on extensive green roofs. Proceedings from 2nd International Green Roof Infrastructure Conference, Awards and Trade Show, Greening Rooftops for Sustainable Communities, 2-4 June 2004, Portland Oregon, the Cardinal Group, Toronto.

[9] Snodgrass E., \& Snodgrass L. 2006. Green Roof Plants: A Resource and Planting Guide. Portland, Oregon. Timber Press, Inc.

[10] [10] VanWort N. D., Rowe D. B., Anderson J. A., Rugh C. L., \& Xiao L. 2005. Watering regime and green roof substrate design impact Sedum plant growth. HortScience, 40, 659-664. and persistence of sedum spp. and native taxa for green roof applications. HortScience, 40, 391-396.

White, J. W., \& Snodgrass E. 2003. Extensive green roof plant selection and characteristics. Proc. 1st Intl. Green Roof Conf.: Greening rooftops for sustainable communities. 1,166-176.

[13] Chow, M. F., M., Abu Bakar, M. F., Roslan, M. A. A., Fadzailah, F. A. Idrus, M. F. Z.,Ismail, N. F., Sidek, L. M., Basri, H., 2015 Hydrological Performance of Native Plant Species within Extensive Green Roof System in Malaysia. ARPN Journal of Engineering and Applied Sciences. 10(15): 1819-6608.

[14] Baumann, N. 2006. Ground-nesting birds on green roofs in Switzerland: Preliminary observations. Urban Habitats, 4,37-50.

[15] Williams N. S. G., Raynor K. J., 2010. Green roofs for wide brown land: opportunities and barriers for rooftop greening in Australia. Urban forest. Urban Green, 9(3), 245-251.

[16] Chow, M. F., Abu Bakar, M.F. 2016. A review of the development and challenges of green roof systems in Malaysia. International journal of Architecture and Environmental Engineering. 10(1): 1620.

[17] Rowe D. B., Rugh C. L., VanWort N., Monterusso M. A., \& Russell D. K. 2003. Green roof slope, substrate depth, and vegetation influence runoff. Proc. 1st N. Amer. Green Roof Conf.: Greening Rooftops for sustainable communities, 1,354-362.

[18] Getter K. L., Rowe D.B., \& Andresen J.A. 2007. Quantifying the effect of slope on extensive green roof stormwater retention. Ecological Engineering, 31,225-231.

[19] Voyde E., Fassman E., Simcock R. 2010. Hydrology of an extensive living roof under subtropical, Climate conditions in Auckland, New Zealand. Journal of Hydrology, 394(3-4), 384-395.

[20] Villarreal, E. L., \& Bengtsson L., 2005. Response of a sedum green-roof to individual rain events. Ecological Engineering, 25(1), $1-7$. 